\title{
ANALISIS KESIAPAN BELAJAR SISWA MENJELANG UJIAN AKHIR PADA PESERTA DIDIK KELAS IX MTS AINUS SYAMSI (STUDI KASUS MENURUT TEORI THORNDIKE)
}

\section{THE ANALYSIS OF STUDENTS' STUDY READINESS TOWARDS FINAL EXAMINATION OF NINTH GRADE STUDENTS OF MTS AINUS SYAMSI (A STUDY CASE BASED ON THORNDIKE THEORY)}

\author{
Nuraeni1), Hading2), Eka Damayanti ${ }^{3)}$ \\ 1,2,3)Fakultas Tarbiyah dan Keguruan Universitas Islam Negeri Alauddin Makassar \\ aeninnur2@gmail.com ${ }^{1)}$, hading@uin-alauddin.ac.id ${ }^{2}$, $\underline{\text { eka.damayanti@uin-alauddin.ac.id }}^{3)}$
}

\begin{abstract}
Abstrak
Tujuan penelitian ini adalah untuk : 1) mengetahui bagaimana kesiapan belajar dalam menghadapi ujian akhir pada peserta didik kelas IX MTs Ainus Syamsi, 2) mengetahui penghambat peserta didik dalam menghadapi ujian akhir pada peserta didik kelas IX MTs Ainus Syamsi. Penelitian ini merupakan jenis penelitian kualitatif yang bersifat deskriptif dengan pendekatan studi kasus. Pada penelitian ini teknik pemilihan sumber data dilakukan dengan purposive sampling yaitu maximum variation sampling. Penarikan sampel yang dilakukan dengan memilih subjek berdasarkan kriteria spesifik yang ditetapkan peneliti. Peneliti melakukan wawancara mendalam untuk menemukan informasi lebih jelas mengenai peserta didik yang menjadi sampel penelitian. Wawancara mendalam dilakukan dengan orang terdekat, teman kelas ataupun dari guru. Subjek yang diteliti adalah Si N dan Si A. Hasil penelitian diperoleh bahwa peserta didik Si N siap menghadapi ujian. Si N menyiapkan diri dalam menghadapi ujian sebagaimana dalam tiga hukum belajar throndike, sedangkan peserta didik Si A kurang siap menghadapi ujian, hal tersebut dikarenakan karena Si A kurang mempersiapkan diri baik fisik maupun mental dalam menghadapi ujian, Si A sangat jarang masuk sekolah, ia sering bolos dan jarang melakukan latihan dalam menghadapi ujian. Selain itu, keretakan hubungan rumah tangga orang tuanya yang mengakibatkan $\mathrm{Si}$ A merasa tidak diperdulikan sehingga tidak menyiapkan diri dalam belajar dan menghadapi ujian.
\end{abstract}

Kata Kunci: kesiapan belajar, teori thorndike, ujian

\begin{abstract}
The objective of this study is to : 1) find out how the readiness of learning in facing the final examination in class IX MTs Ainus Syamsi students, 2) know the inhibitors of students in facing the final examination in class IX MTs Ainus Syamsi students. This research is a descriptive qualitative research with a case study approach. In this study, the technique of selecting data sources is done by purposive sampling, namely maximum variation sampling. Sampling is done by selecting subjects based on specific criteria set by researcher. Researcher conducted in-depth interviews to find clearer information about students who became the sample of research. In-depth interview are conducted with close friends, classmates or teachers. The subject studied were student $N$ and student $A$. The results of the study were obtained that student $N$ student is ready for the examination. $N$ prepared himself for the examination as in three Thorndike study laws, while student A are less ready to face the examination, it is because student $A$ is less prepared both physically and mentally in facing in facing examination, student $A$ is rarely in school often misses and rarely examination. In
\end{abstract}


addition, his parents' broken family ties caused student $A$ to feel left out and unable to prepare for his studies and to face examination.

Keywords: learning readiness, thorndike theory, examination

How to Cite: Nuraeni, Hading, \& Damayanti, E. (2019). Analisis kesiapan belajar siswa menjelang ujian akhir pada peserta didik kelas IX MTs Ainus Syamsi (studi kasus menurut teori thorndike). Al-Asma: Journal of Islamic Education, 1(1), 29-41.

\section{PENDAHULUAN}

Ujian atau evaluasi adalah suatu penilaian yang digunakan untuk mengukur tingkat pemahaman peserta didik. Evaluasi biasanya diberikan setelah terlaksananya kegiatan belajar mengajar. Belajar adalah cara seseorang untuk mengetahui suatu perihal yang belum bisa dilakukan. Pelaksanaan proses belajar mengajar merupakan kejadian atau peristiwa interaksi antara pendidik dan peserta didik yang diharapkan menghasilkan perubahan pada peserta didik, dari belum mampu menjadi mampu, dari belum terdidik menjadi terdidik, dari belum kompeten menjadi kompeten. Inti dari proses belajar mengajar adalah efektivitasnya. Tingkat efektivitas pembelajaran sangat dipengaruhi oleh perilaku pendidik dan perilaku peserta didik. Perilaku peserta didik yang efektif, antara lain motivasi atau semangat belajar, keseriusan, perhatian, kerajinan, kedisiplinan, keingintahuan, pencatatan, pertanyaan, senang melakukan latihan soal, dan sikap belajar yang positif. Sebagaimana pendapat (Dimyati dan Mudjono, 2002) dalam buku belajar dan pembelajaran menyatakan bahwa guru adalah pemegang kunci pembelajaran dan pelaku aktif dalam pembelajaran adalah peserta didik.

Proses belajar mengajar merupakan proses yang terpenting karena dari sinilah terjadi interaksi langsung antara pendidik dan peserta didik. Di sini pula campur tangan langsung antara pendidik dan peserta didik berlangsung sehingga dapat dipastikan bahwa hasil pendidikan sangat tergantung dari perilaku pendidik dan perilaku peserta didik. Proses belajar mengajar merupakan serangkaian aktivitas yang terdiri dari persiapan, pelaksanaan, dan evaluasi pembelajaran. Ketiga hal tersebut merupakan rangkaian utuh yang tidak dapat dipisah-pisahkan. Peristiwa pembelajaran adalah gambaran sederhana tentang paradigma aktivitas peserta didik dan pendidik yang terjadi secara komplementer (saling isi mengisi) dan saling ketergantungan dalam situasi pembelajaran (Yaumi, 2012: 46).

Hal ini sejalan dengan definisi belajar menurut Throndike menurut (Ulfiani Rahman, 2014) dalam buku Memahami Psikologi dalam Pendidikan Teori dan Aplikasi, dimana menurutnya belajar adalah proses interaksi antara stimulus dan respons. Stimulus yaitu apa saja yang dapat merangsang terjadinya kegiatan belajar seperti pikiran, perasaan atau hal-hal lain yang dapat ditangkap melalui alat indera. Sedangkan respons yaitu interaksi yang dimunculkan peserta didik ketika belajar, yang juga dapat berupa pikiran, perasaan atau gerakan/tindakan.

Kesiapan belajar peserta didik sangat dibutuhkan. Akan tetapi, tidak semua peserta didik mampu menerapkan. sebagian hasil wawancara tertulis yang yang dilakukan kepada peserta didik yang pertama kali dilakukan peneliti untuk mengetahui bagaimana kesiapan peserta didik MTs Ainus Syamsi dalam menghadapi ujian. Alasan mereka pun berbeda-beda ada yang mengatakan mereka siap, tetapi secara prakteknya belum nampak. 
Namun ada juga peserta didik yang mengatakan mereka sudah siap menghadapi ujian, kesiapan mereka dengan belajar, menyiapkan mental dan sering membaca buku.Selain itu, belum diberikannya kelas tambahan (les) oleh guru kepada peserta didik. Menurut mereka ujian merupakan suatu hal yang penting, karena dengan ujian dapat mengasah otak dan mengetahui pelajaran-pelajaran yang telah diajarkan oleh guru, dan nilai sangatlah penting untuk masa depan. Adapula yang beranggapan bahwa ujian adalah penentu kelulusan dan mengajarkan diri untuk lebih giat untuk belajar. Guru memberikan motivasi kepada peserta didik agar giat belajar, tetapi guru tidak pernah memberitahu peserta didik tentang peserta didik yang tidak lulus pada tahun sebelumnya. Padahal itu bisa menjadi motivasi agar mereka belajar dengan sungguh-sungguh agar tidak terulang lagi adanya peserta didik yang tidak lulus.

Selain itu, berdasarkan wawancara yang dilakukan pada guru menyatakan bahwa kesiapan belajar peserta didik menghadapi ujian sudah hampir 70\%, setiap guru memberikan himbauan bahwa tak lama lagi mereka akan melakukan ujian, mereka diberikan motivasi untuk menghadapi ujian dengan membentuk kelompok belajar. Dalam kelompok belajar tersebut mereka hanya sekedar bertukar pikiran tentang pelajaran yang mereka pelajari. Kelompok belajar ini pun masih kurang efisien dimana hanya beberapa peserta didik saja yang melakukan kelompok belajar tersebut. Selain itu, pandangan guru tentang bagaimana pentingnya peserta didik menghadapi ujian, gurunya mengatakan bahwa UN penting untuk peserta didik sebab UN merupakan tolak ukur yang digunakan untuk mengukur kemampuan peserta didik dalam belajar selama 3 tahun. Ada juga yang beranggapan bahwa ujian sangat penting sebab untuk menghadapi ujian harus ada persiapan yang matang dari peserta didik. Menurut beberapa guru perilaku yang tampak dari peserta didik ketika diinfokan akan dilakukan ujian, ada beberapa peserta didik yang gembir, kaget, ada yang biasa-biasa saja, ada juga terlihat khawatir dan was-was. Selain itu guru juga memberikan arahan-arahan kepada peserta didik dalam mengerjakan ujian dalam bentuk simulasi. Adapun strategi yang diberikan guru untuk meningkatkan kesiapan belajar peserta didik dalam menghadapi ujian adalah dengan mengajarkan pembahasan soal-soal ujian tahun sebelumnya, berdasarkan SKL. Selain itu, bimbingan ekstra les dan cara mengerjakan soal pilihan ganda dengan menjawab soal yang dianggap mudah terlebih dahulu. Peserta didik belum menyiapkan diri dalam menghadapi ujian, dikarenakan peserta didik masih menganggap ujian adalah hal yang menakutkan sehingga menjadikannya beban (fisiologis), dan kurangnya motivasi dari orang tua. Selain itu materi pembelajaran tidak dikuasai khususnya materi pembelajaran pemahaman dan perhitungan dan malas masuk belajar.

Oleh karena itu, maka peneliti akan melakukan penelitian terhadap beberapa peserta didik di MTs Ainus Syamsi, untuk mengetahui bagaimana perkembangan kesiapan belajar peserta didik, apakah akan tetap sama dengan wawancara yang dilakukan ataukah akan meningkat seiring dengan semakin dekatnya ujian akhir sekolah dan hambatan apa saja yang menyebabkan mereka tidak menyiapkan diri dalam menghadapi ujian.

Tujuan dilakukannya penelitian ini adalah :

a. Untuk mengetahui bagaimana kesiapan peserta didik dalam menghadapi ujian peserta didik kelas IX MTs Ainus Syamsi.

b. Untuk mengetahui penghambat peserta didik kelas IX MTs Ainus Syamsi dalam menghadapi ujian akhir sekolah. 
Belajar merupakan salah satu faktor yang mempengaruhi dan berperan penting dalam pembentukan pribadi dan perilaku individu. Belajar merupakan proses yang harus terus-menerus, yang tidak pernah berhenti dan tidak terbatas pada dinding kelas. Belajar merupakan proses yang harus terus-menerus, yang tidak pernah berhenti dan tidak terbatas pada dinding kelas. Hal ini berdasarkan pada asumsi bahwa sepanjang kehidupan manusia akan selalu dihadapkan pada masalah atau tujuan yang ingin dicapainya. Dalam proses mencapai tujuan itu, manusia akan dihadapkan pada berbagai rintangan. Manakala rintangan sudah dilaluinya, maka manusia akan dihadapkan pada tujuan atau masalah baru; untuk mencapai tujuan baru itu manusia akan dihadapkan pada rintangan baru pula, yang kadang-kadang rintangan itu semakin berat. Demikianlah siklus kehidupan dari mulai lahir sampai kematian manusia akan senantiasa dihadapkan pada tujuan dan rintangan yang terus menerus. Dikatakan manusia yang sukses dan berhasil manakala ia dapat menembus rintangan itu; dan dikatakan manusia gagal manakala ia tidak dapat melewati rintangan yang dihadapinya. Atas dasar itulah, sekolah yang berperan sebagai wahana untuk memberikan latihan bagaimana cara belajar. Melalui kemampuan bagaimana cara belajar peserta didik akan dapat belajar memecahkan setiap rintangan yang dihadapi sampai akhir hayatnya (Sanjaya, 2006: 110).

Dikatakan manusia yang sukses dan berhasil manakala ia dapat menembus rintangan itu; dan dikatakan manusia gagal manakala ia tidak dapat melewati rintangan yang dihadapinya. Atas dasar itulah, sekolah yang berperan sebagai wahana untuk memberikan latihan bagaimana cara belajar. Melalui kemampuan bagaimana cara belajar peserta didik akan dapat belajar memecahkan setiap rintangan yang dihadapi sampai akhir hayatnya (Sanjaya, 2006: 110). Ketuntasan kegiatan pembelajaran sangat ditentukan oleh kepedulian, kemauan, kepabilitas dan kerja keras semua unsur (Daryanto, 2013: 312).

Di era globalisasi ini peserta didik dituntut harus lebih aktif dan mandiri dalam proses belajar, tidak pasif dan hanya mengharapkan atau mengandalkan guru dan orang lain sebagai pemberi materi. Misalnya dalam suatu sekolah ada seorang guru yang tidak bisa hadir di dalam kelas untuk memberikan materi pelajaran maka peserta didik harus berinisiatif mencari bahan atau sumber belajar sendiri dengan cara memanfaatkan perpustakaan sekolah, dengan mencari buku pelajaran yang sesuai dan belajar mandiri untuk memahami materi atau pelajaran yang belum atau yang sudah diberikan oleh guru tersebut.

Kegiatan pembelajaran dirancang untuk memberikan pengalaman belajar yang melibatkan proses mental dan fisik melalui interaksi antar peserta didik, peserta didik dengan guru, lingkungan dan sumber belajar lainnya dalam rangka pencapaian tujuan pembelajaran. Pengalaman belajar yang dimaksud adalah kecakapan yang perlu dikuasai oleh peserta didik sehingga pembelajaran disini lebih ditekankan pada proses belajarnya (Warsita, 2001: 86).

Dalam kegiatan belajar mengajar, guru memegang peran yang sangat penting. Guru menentukan segalanya, mau diapakan peserta didik? Apa yang harus dilakukan peserta didik?. Semuanya tergantung guru. Oleh karena itu, pentingnya peran guru, maka biasanya proses pengajaran hanya berlangsung manakala ada guru; dan tak mungkin ada proses pembelajaran tanpa ada guru. Sehubungan dengan proses pembelajaran yang berpusat pada guru, maka minimal ada tiga peran utama yang harus dilakukan guru, yaitu 
guru sebagai perencana, sebagai penyampai informasi dan guru sebagai evaluator. Sebagai perencana pengajaran, sebelum proses pengajaran, guru harus menyiapkan berbagai hal yang diperlukan, misalnya materi pelajaran apa yang harus disampaikan, bagaimana cara menyampaikannya, media apa yang harus digunakan dan lain sebagainya. Dalam melaksanakan perannya sebagai penyampai informasi, sering guru menggunakan metode ceramah sebagai metode utama. Metode ini merupakan metode yang dianggap ampuh dalam proses pembelajaran. Karena pentingnya metode ini, biasanya guru merasa mengajar apabila sudah melakukan ceramah dan tidak mengajar jika tidak menggunakan metode ceramah. Sedangkan sebagai evaluator, guru juga berperan dalam menentukan alat evaluasi keberhasilan pengajaran. Biasanya kriteria keberhasilan proses pengajaran diukur dari sejauh mana peserta didik dapat menguasai materi yang disampaikan guru. Dalam pelaksanaan pembelajaran, proses interaksi antara peserta pelatihan dan pengajar yang menggunakan segala sumber daya sesuai dengan perencanaan yang telah dipersiapkan sebelumnya dalam rangka mencapai tujuan. Dalam pelaksanaan pembelajaran ini harus selalu mengingat prinsip pembelajaran yait mengalirkan kompetensi kunci dalam setiap kegiatan dan aktivitasnya yang selalu bersentral pada fokus peserta pendidikan dan pelatihan. Untuk itu hal yang perlu dipertimbangkan dalam pelaksanaan pembelajaran, antara lain pendekatan pembelajaran, metode pembelajaran, tahap pembelajaran dan tempat pelaksanaan pembelajaran (Sanjaya, 2006: 96-97).

Pengelolaan kegiatan belajar mengajar merupakan pembelajaran utuh dan menyeluruh yang dimulai dari perencanaan dan pelaksaan hingga evaluasi pembelajaran, termasuk evaluasi program dalam rangka mencapai tujuan pendidikan seperti yang telah ditentukan. Keberhasilan kegiatan mengajar atau pendidikan pelatihan untuk mewujudkan mutu tamatan yang sesuai dengan profil kompetensi yang telah diformulasikan dalam kurikulum sangat ditentukan oleh mutu pengelolaan kegiatan belajar mengajar dengan pendekatan tuntas. Ketuntasan kegiatan pembelajaran sangat ditentukan oleh kepedulian, kemauan, kepabilitas dan kerja keras semua unsur (Daryanto, 2013: 312).

Dengan kesiapan belajar yang dimilikinya maka peserta didik mampu menjadi generasi penerus bangsa ini serta mampu bersaing hidup secara mandiri, mampu menghadapi tantangan kehidupan dan memiliki kualitas serta karakter yang baik. Ada beberapa aspek yang menyebabkan peserta didik tidak mempunyai kesiapan dalam belajar yaitu kondisi fisik, mental dan emosional, Kebutuhan-kebutuhan, motif dan tujuan, serta keterampilan, pengetahuan dan pengertian yang lain yang telah dipelajari.

Para ahli mengemukakan beberapa teori belajar yang menggambarkan bagaimana pendekatan yang dapat dilakukan dalam proses pembelajaran, bagaimana guru dalam menghadapi siswa di kelas dan bagaiaman mengetahui karakteristi siswa dalam belajar. Beberapa teori belajar yang dikemukakan oleh para ahli, antara lain teori- teori belajar Behaviorisme, teori belajar Kognitif dan teori belajar Throndike.

Behaviorisme merupakan adalah aliran psikologi yang memandang individu hanya dari sisi fenomena jasmaniah, dan mengabaiakan aspek-aspek mental. Dengan kata lain, behaviorisme tidak mengakui adanya kecerdasan, bakat, minat, dan perasaan individu dalam suatu belajar. Peristiwa belajar semata-mata melatih refleks-refleks sedemikian rupa sehingga menjadi kebiasaan yang dikuasai individu. Dalam teori-teori belajar Behaviorisme termasuk teori Pavlov, Skinner dan Throndike 
Teori belajar gagasan Ivan Pavlov disebut dengan teori pembiasaan klasik (classical conditioning). Kata classical yang mewakili nama teori ini semata-mata dipakai untuk menghargai karya Pavlov yang dianggap paling dahulu di bidang conditioning (upaya pembiasaan) dan untuk membedakannya dari teori conditioning lainnya (Gleitment, 1986). Selanjutnya, mungkin karena fungsinya, teori Pavlov juga dapat disebut respondent conditioning (pembiasaan yang dituntut). Teori ini sering disebut juga contemporary behavioris atau juga disebut S-R psychologists yang berpendapat bahwa tingkah laku manusia itu dikendalikan oleh ganjaran (reward) atau penguatan (reinforcement) dari lingkungan (Hergenhanh \& Olson, 1997). Jadi, tingkah laku belajar mendapat jalinan yang erat antara reaksi behavioral dengan stimulasinya. Guru yang menganut pandangan ini bahwa masa lalu dan masa sekarang dan segenap tingkah laku merupakan reaksi terhadap lingkungan mereka merupakan hasil belajar. Teori ini menganalisis kejadian tingkah laku dengan mempelajari latar belakang penguatan (reinforcement) terhadap tingkah laku tersebut (Rahman, 2014: 33-34).

Menurut Skinner (Hall \& Lindzey dalam Ulfiani Rahman, 2014: 47-48) unsur yang terpenting dalam belajar adalah penguatan (reinforcement) dan hukuman (punishment). Penguatan (reinforcement) adalah konsekuensi yang meningkatkan probabilitas bahwa suatu perilaku akan terjadi. Sebaliknya, hukuman (punishment) adalah konsekuensi yang menurunkan probabilitas terjadinya suatu perilaku. Lebih lanjut dijelaskan bahwa teori belajar operan kondisioning Skinner (Ulfiani, 2014: 52-53) memberi banyak konstribusi untuk praktik pengajaran. Konsekuensi penguatan dan hukuman adalah bagian dari kehidupan dan murid. Jika dipakai secara efektif, pandangan teori ini akan mendapat bantuan para guru dalam pengelolaan kelas. Demikian pula prinsip-prinsip dan hukumhukum belajar yang tertuang dalam teori ini akan membantu guru dalam menggunakan pendekatan pengajaran yang cocok untuk mencapai hasil belajar dan perubahan tingkah laku yang positif bagi anak didik.

Piaget merupakan salah seorang tokoh yang disebut-sebut sebagai pelopor aliran konstruktivisme. Salah satu sumbangan pemikirannya yang banyak digunakan sebagai rujukan untuk memahami perkembangan kognitif individu. Menurut Piaget bahwa perkembangan kognitif individu meliputi empat tahap yaitu sensor motorik, pra operasional, operasioanal konkret, dan operasional formal. Pokok pandangan Gestalt adalah bahwa obyek atau peristiwa tertentu akan dipandang sebagai sesuatu keseluruhan atau terorganisasikan

Adapun Menurut Throndike, belajar merupakan peristiswa terbentuknya asosiasiasosiasi antara peristiwa yang disebut stimulus (s) dengan respons (R). Stimulus adalah suatu perubahan dari lingkungan eksternal yang menjadi tanda untuk mengaktifkan organisme untuk bereaksi atau berbuat.Sedangkan respons adalah tingkah laku yang dimunculkan karena adanya perangsang (Hergenhahn \& Olson, 1997). Adapaun teori Throndike ini disebut teori koneksionisme. Belajar adalah pembentukan hubungan stimulus dan respons sebanyak-banyaknya. 
Thorndike memandang belajar sebagai suatu usaha memecahkan problem. Berdasarkan eksprimen yang dilakukanya, ia memperoleh tiga buah hukum dalam belajar (Hergenhahn \& Olson, 1997), yaitu:

a. Hukum Kesediaan

Yaitu kesediaan dari segi psikimotor, efektif, kognitif sebelum boleh belajar.Hukum ini mengajarkan bahwa dalam memberikan respons, subjek harus siap dan disiapkan.Hukum ini menyangkut syarat kematangan dalam pengajaran, baik kematangan fisik, maupun mental dan intelek. Stimulus tidak akan direspons atau responsya akan lemah saja, bila pelajar kurang atau belum siap.

b. Hukum Latihan

Latihan yang diulang-ulang untuk ditingkatkan kemahiran.Hukum ini menyatakan bahwa respons terhadap stimulus dapat diperkuat dengan seringnya respons itu dipergunakan.Hal ini menghasilkan implikasi bahwa praktik, khususnya pengulangan dalam pengajaran adalah penting dilakukan.

c. Hukum Kesan (efek)

Kesan yang menyenangkan meningkatkan hubungan antara rangsangan dan gerak balas. Hukum menyatakan bahwa tercapainya keadaan yang memuaskan akan memperkuat hubungan antara stimulus dan respons. Maksudnya bila respons terhadap stimulus menimbulkan sesuatu yang memuaskan, misalnya menyenangkan, maka subjek akan memberikan respons yang lebih cepat dan intens. Bila hubungan stimulus dan respons tidak diikat oleh sesuatu maka respons itu akan melemah bahkan tidak akan ada respons sama sekali.

Secara umum hukum ini berbunyi " sesuatu yang menimbulkan efek yang mengenakkan akan cenderung diulangi dan sebaliknya". Hukum ini dapat bermanfaat didalam proses belajar mengajar bila program pengajaran menghasilkan keuntungan pada murid. Kalau demikian, hadiah dalam ukuran yang tepat serta hukuman yang wajar akan bermanfaat bagi keberhasilan pendidikan. Selain itu, hasil belajar itu sendiri berfungsi sebagai hadiah (yang mengenakkan) bagi murid.

Terdapat beberapa prinsip belajar yang dikemukakan oleh thorndike (Hergenhahn\&Olson, 1997), antara lain:

a. Pada saat orang saat seseorang berhadapan dengan situasi yang baru, berbagai respons yang dilakukan. Adapun respons tiap-tiap individu tidak sama walaupun menghadapi situasi yang sama, sehingga akhirnya tiap individu mendapatkan respons atau tindakan yang cocok dan memuaskan. Seperti seseorang yang sedang dihadapkan dengan problema keluarga maka seseorang akan menghadapi dengan respons yang berbeda-beda walaupun situasinya sama, orang tua dihadapkan dengan perilaku anak yang kurang wajar.

b. Dalam diri setiap orang sebenarnya sudah tertanam potensi untuk mengadakan seleksi terhadap unsur-unsur yang penting dan kurang penting, hingga akhirnya menemukan respons yang tepat. Seperti orang yang dalam masa perkembangan dan menyongsong masa depan maka sebenarnya dalam diri orang tersebut sudah mengetahui unsur penting yang harus dilakukan demi mendapatkan hasil yang sesuai dengan yang diinginkan.

c. Orang cenderung memberikan respons yang sama tehadap situasi yang sama. Seperti apabila seseoarang dalam keadaan stress karena diputus oleh kekasihnya dan ia 
mengalami ini berulang kali, maka sudah barang tentu ia akan merespons situasi tersebut seperti yang dilakukan dahulu (Rahman. 2014: 58-59).

Secara teoritis hasil penelitian ini diharapkan dapat dijadikan sebagai bahan pengembangan ilmu pengetahuan. Adapun secara praktis bagi guru sebagai masukan dalam menentukan langkah yang tepat dalam meningkatkan kesiapan belajar peserta didik mengahadapi ujian akhir sekolah berdasarkan teori throndike tersebut.Bagi Peserta didik untuk meningkatkan hasil belajar peserta didik dan membantu peserta didik dalam menyiapkan diri dalam menghadapi ujian akhir sekolah. Adapun bagi penulis dapat menambah pengalaman dan wawasan baik dalam bidang penelitian pendidikan maupun penulisan karya ilmiah. Bagi Sekolah untuk perkembangan kualitas sekolah secara institusional, berupa peningkatkan proses belajar mengajar serta untuk peningkatkan hasil belajar peserta didik di sekolah. Dan bagi pembaca untuk menambah wawasan dan bahan referensi dalam meningkatkan hasil belajar peserta didik khususnya pada mata pelajaran fisika.

\section{METODE PENELITIAN}

Penelitian ini tergolong jenis penelitian kualitatif. Penelitian kualitatif menurut Bogdan dan Taylor dalam Lexy J. Moleong adalah suatu jenis penelitian yang menggunakan data deskriptif, yang berupa kata-kata tertulis atau lisan dari orang atau pelaku yang diamati (Steren, 1993: 5).

Penelitian ini merupakan penelitian kualitatif yang bersifat deskriptif, karena dalam penelitian ini berusaha menggambarkan suatu obyek tertentu yang dijadikan penelitian (Sukamadinata, 2010: 60). Lokasi Penelitian ini dilakukan di MTs Ainus Syamsi tepatnya Jl. Masembo No. 80 Kel. Bajubodoa Kabupaten Maros.

Secara metodologi pendekatan penelitian yang dilakukan adalah studi kasus. Desain Deskriptif Kualitatif studi kasus merupakan penelitian eksplorasi dan memainkan peranan yang amat penting dalam menciptakan hipotesis atau pemahaman orang tentang berbagai sosial (Bungin, 2007: 69). Dari sudut pandang keilmuan pendekatan yang digunakan adalah pendekatan ilmu psikologi pendidikan dan strategi pembelajaran. Psikologi adalah ilmu yang mempelajari segala tingkah laku organisme yang hidup terutama manusia. Psikologi pendidikan adalah aplikasi atau penerapan prinsip-prinsip psikologi dalam dunia pendidikan (Nurwanita, 2003: 5).

Dalam penelitian ini teknik pemilihan sumber data dilakukan dengan purposive sampling yaitu maximum variation sampling. Adapun kriteria pemilihan sampel adalah peserta didik kelas IX MTs Ainus Syamsi yang akan menghadapi ujian, pentingnya melakukan latihan-latihan dalam menjawab soal, khususnya soal-soal UN MTS/sederajat. Agar tidak muncul penyesalan saat tidak lulus ujian sebagai akibat dari tidak mempersiapkan diri dengan belajar sebelumnya.

Metode yang digunakan oleh peneliti untuk mengumpulkan data adalah wawancara mendalam dan observasi nonpartisipan. Wawancara yang mendalam adalah tanya jawab yang terbuka untuk memperoleh data tentang maksud hati partisipan, bagaimana menggambarkan dunia mereka dan bagaimana mereka menjelaskan atau menyatakan perasaannya tentang kejadian yang penting dalam hidupnya (Satori dan Komariah, 2011: 130). Wawancara dilakukan kepada warga sekolah yaitu peserta didik dan guru. Observasi yang dilakukan adalah observasi nonpartisipan, dimana observasi 
nonpartisipan adalah observasi yang dilakukan oleh peneliti yang berperan mengumpulkan data, tidak terlibat langsung dalam proses pembelajaran. Pemilihan subyek penelitian, berdasarkan observasi yang dilakukan peneliti terhadap tingkah laku peserta didik di lingkungan sekolah.

Selain itu melakukan dokumentasi. Dokumentasi adalah metode pengumpulan data langsung dari tempat penelitian, meliputi buku-buku yang relevan, peraturanperaturan, laporan kegiatan, foto-foto, file documenter, file recorder dan data lain yang relevan dengan penelitian. Teknik pengumpulan data dengan dokumentasi ialah pengambilan data yang diperoleh melalui dokumen-dokumen. Keuntungan menggunakan dokumentasi ialah biayanya relatif murah, waktu dan tenaga lebih efisien.

Instrumen penelitian yang digunakan diantaranya adalah Pedoman wawancara. Pedoman wawancara digunakan untuk mengetahui tanggapan peserta didik mengenai kesiapannya dalam menghadapi ujian dan hambatan apa saja yang dialami peserta didik. Setelah melakukan wawanncara, lalu memilah manakah subyek yang termasuk dalam kategori yang akan diteliti oleh pengamat yang selanjutnya akan diwawancarai secara mendalam hingga menggambarkan atau mendeskripsikan tentang subyek, dan bagaimana kesiapan subyek dalam menghadapi ujian serta hambatan atau kendala apa yang dialami oleh subyek dalam menghadapi ujian.

Teknik analisis data yang digunakan berupa teknik koding yang bersifat deskriptif. Telaah data, Reduksi data, dan penyimpulan dan verifikasi. Untuk menetapkan keabsahan data yang diperoleh pada penelitian maka diperlukan teknik pemeriksaan. Pelaksanaan pemeriksaan didasarkan atas empat kriteria tertentu yaitu derajat kepercayaan (credibelity), keteralihan (transferability), kebergantungan (dependability) dan kepastian (confirmability) (Emzir, 2014: 50).

\section{HASIL DAN PEMBAHASAN}

Berdasarkan hasil penelitian tersebut diperoleh bahwa subyek dalam penelitian ini belum secara optimal memiliki kesiapan belajar. Masih terdapat peserta didik yang kurang mempersiapkan diri dengan belajar dalam menghadapi ujian, baik secara fisik maupun mental. Mempersiapkan diri dalam belajar mengadapi ujian tidak hanya sematamata ikut pelajaran pada saat les. Tetapi mengulangi pelajaran ataupun les yang sudah diberikan guru di kelas. Sebagaimana dalam penelitian yang saya lakukan, di peroleh bahwa kesiapan belajar menghadapi ujian berdasarkan tiga aspek, yaitu

\section{Kesediaan}

Salah satu peserta didik yang mengoptimalkan kesediaan dalam belajar adalah Si N. Ia termasuk anak yang pintar. Ia sudah mempersiapkan fisik dan mentalnya dalam menghadapi ujian.

Si A merupakan salah satu peserta didik yang kurang mengoptimalkan kesediaan belajar dalam menghadapi ujian, baik dari segi fisik maupun mentalnya.

\section{Latihan}

Si N sudah mempergunakan respons dari stimulus yang diberikan guru untuk giat belajar dengan baik. Si N semakin giat belajar menghadapi ujian, ia menyibukkan diri dengan belajar. Dengan jarangnya melakukan pengulangan atau latihan menjawab soal ujian yang dilakukan oleh Si A, membuatnya semakin kurang siap ia menghadapi ujian. 


\section{Efek/Kesan}

Pada diri Si N, sudah ada kesadaran akan pentingnya belajar menghadapi ujian. Selain itu prestasi Si N yang sering meningkat karena belajar dengan sungguh-sungguh merupakan faktor penunjang yang membuatnya semakin giat belajar, agar bisa menjawab soal ujian dan baik dan benar.

Karena kurangnya kesiapan serta latihan yang dilakukan oleh Si A dalam menghadapi ujian, mengakibatkan Si A tidak akan optimal dalam menjawab soal ujian yang disebabkan oleh faktor internal seperti tidak adanya kesadaran dalam diri Si A untuk belajar menghadapi ujian. Adapun faktor eksternalnya karena Si A terpengaruh oleh lingkungan dan pergaulannya. Hal ini sesuai dengan hukum dalam belajar yang dilakukan oleh Throndike, yaitu Hukum Efek / Kesan. Hukum ini menyatakan bahwa tercapainya keadaan yang memuaskan, akan memperkuat hubungan antara stimulus dan respons. Maksudnya bila respons terhadap stimulus menimbulkan sesuatu yang memuaskan, misalnya menyenangkan, maka subyek akan memberikan respons yang lebih cepat dan intens. Bila hubungan stimulus dan respons tidak diikat oleh sesuatu yang menyenangkan, maka respons akan melemah bahkan tidak akan ada respons sama sekali.

Adapun penelitian sebelumnya yang dianggap relevan dengan penelitian ini diantaranya penelitian yang dilakukan oleh Akhmad Wahid Abdillah. Dimana hasil penelitiannya menunjukkan bahwa terdapat pengaruh yang signifikan antara kesiapan belajar terhadap hasil pembelajaran bahasa Arab Kajian Kitab Ibnu Aqil Di Kelas Alfiyyah 2 Pondok Pesantren Al-Luqmaniyah Yogyakarta Tahun akademik 2014/2015. Terdapat hubungan yang cukup kuat antara kesiapan belajar terhadap hasil pembelajaran bahasa Arab. Sedangkan untuk penelitian saya ini, terdapat hubungan yng relevan pula antara kesiapan belajar peserta didik yang seperti menyiapkan diri, baik jasmani dan rohani, memperbanyak latihan dan menyadari akan pentingnya belajar menghadapi ujian. Sehingga hasil ujian yang didapatkan juga akan memuaskan.

Penelitian Sintia Novita Sari juga menjelaskan bahwa terdapat pengaruh yang signifikan antara kesiapan belajar dengan keaktifan peserta didik. Keaktifan peserta didik dalam mengikuti pelajaran dapat menjadi salah satu bentuk kesiapan peserta didik dalam belajar. Unsur keaktifannya meliputi faktor internal dan faktor eksternal. Faktor internal meliputi kesiapan belajar peserta didik dalam mengikuti proses belajar, mendengarkan apa yang dijelaskan oleh guru, dan melengkapi catatan dengan mengerjakan tugas yang diberikan guru. Faktor internal ini sudah dilakukan oleh Si N, ia sering mengerjakan tugas yang diberikan guru, melengkapi catatan dan lebih banyak meluangkan waktu belajar di rumah daripada bergaul bersama temannya. Si $\mathrm{N}$ tidak terpengaruh oleh pergaulan diluar, seperti teman-temannya yang kebanyakan terpengaruh pergaulan, sering keluyuran apabila pulang sekolah. Si N hanya tinggal di rumah ataupun dilingkungan rumahnya saja. Ia terkenal juga dengan sosoknya yang pendiam dan hanya bergaul bersama orang-orang yang ia rasa akrab.

Sedangkan Si A sangat malas belajar di sekolah, karena kemalasannya di sekolah, bisa dipastikan ia tidak melengkapi catatan dan malas mengerjakan tugas yang diberikan oleh guru. Ia hanya sering keluar bergaul bersama teman-temannya. Adapun faktor eksternal meliputi dukungan atau motivasi dari keluarga dan masyarakat. Kurangnya perhatian dan dukungan dari orang tua Si A yang membuatnya merasa tidak ada yang memperdulikannya, sehingga ia mencari orang-orang yang mengerti akan dirinya dan 
merasa nyaman bergaul bersama orang-orang tersebut tanpa memikirkan apakah itu baik untuknya atau tidak. Walaupun neneknya sering memperhatikannya dan memenuhi keinginannya, tetapi itu tidak membuat Si A masih merasa kurang diperhatikan. Perhatian yang diinginkan adalah dari orang tuanya, utamanya orang tua kandungnya. Apalagi orang tua kandung Si A sudah memilih berpisah dan mempunyai kelurga masing-masing. Keakraban dengan saudara tirinya pun tidak dimiliki oleh Si A. Ia tidak pernah bergaul bersama saudara tirinya. Si A juga tidak diperhatikan oleh ibu tiri dari bapaknya dan bapak tiri dari ibu kandungnya. Selain itu Si A tidak tinggal bersama bapak maupun ibu kandungnya, Si A hanya tinggal bersama neneknya.

Pada faktor eksternal ini pula yang membuat Si $\mathrm{N}$ jadi giat belajar, karena dukungan dari keluarganya untuk belajar, apalagi di lingkungan rumahnya dan masyarakat, orang-orang yang taat beribadah. Dimana di kampungnya merupakan salah satu kelompok Remaja Masjid yang rajin dan aktif melakukan kegiatan, seperti pengajian. Sedangkan Si A mengalami masalah dari segi keluarganya yang mana orang tuanya berpisah, ia kurang mendapatkan perhatian dari kedua orang tuanya dan teman bergaul atau lingkungannya kebanyakan adalah anak yang kurang baik. Si A sangat membutuhkan perhatian dari kedua orang tunya. Tetapi orang tua Si A utamanya orang tua kandungnya kurang memperhatikannya. Mereka memberikan fasilitas berupa motor dan uang, tetapi tidak mengontrol kegiatan dan hal apa saja yang dilakukanoleh Si A. Sehingga Si A bebas melakukan apa saja yang ingin dilakukannya, entah itu baik atau buruk.

Sebagaimana penelitian yang dilakuakan oleh Rahmiati, bahwa banyaknya peserta didik yang tidak tuntas pada mata pelajaran IPA biologi. Ini mungkin di sebabkan oleh faktor yang salah satunya faktor kesiapan belajar. Sebagaimana menurut Mulyani (2003: 28) bahwa kurangnya kesiapan peserta didik dalam belajar apabila terus dilakukan dapat mengganggu peserta didik dalam menyerap mata pelajaran yang diberikan. Apabila kesiapan belajar tidak diperhatikan oleh guru, maka akan berakibat semakin bertambahnya materi yang tidak mampu diserap dan dipahami oleh peserta didik. Hal ini dapat mengakibatkan kekurangmampuan peserta didik dalam menjawab pertanyaan yang diberikan dan akhirnya berdampak pada rendahmya hasil belajar peserta didik. Oleh karena itu, kesiapan belajar yang terjadi pada peserta didik harus dianalisis dan diperbaiki agar tujuan dari pembelajaran bisa terpenuhi. Kesiapan ini perlu diperhatikan dalam proses belajar, karena jika peserta didik belajar dan peserta didik tersebut sudah memiliki kesiapan, maka hasil belajarnya akan lebih baik.

Penelitan Rahmiati ini relevan dengan penelitian yang dilakukan oleh peneliti, dimana kesiapan belajar peserta didik bukan hanya dipersiapkan oleh peserta didik saja, tetapi guru juga, guru memiliki peran penting dalam mengarahkan peserta didik bagaimana caranya agar bisa memahami materi yang diberikan sehingga mampu menjawab soal-soal ujian dengan benar. Guru juga memilihkan strategi yang tepat yang mudah dipahami oleh peserta didik dalam menjawab soal-soal ujian. Guru juga selalu memberikan motivasi agar peserta didik semakin giat belajar, utamanya di rumah. Kurangnya kesiapan yang dilakukan peserta didik dapat mengakibatkan ia akan kesulitan dalam menghadapi ujian. Guru juga dapat berkomunikasi dengan orang tua untuk menanyakan bagaimana kesiapan belajar peserta didik di rumah, sebagai penyambung kontrol guru di rumah. Peran orang tua dan guru yang terjalin dengan baik, akan membantu juga peserta didik menyiapkan diri dalam belajar. 
Sebagaimana dalam penelitian yang dilakukan oleh Dwi Indah Maharani yang menyatakan bahwa dalam kegiatan belajar sangat, peserta didik sangat membutuhkan motivasi orang tua dan aktivitas belajar. Motivasi orang tua merupakan dorongan/dukungan dari orang tua kepada anak dalam mencapai sesutu yang diharapkan karena orang tua merupakan orang yang paling mempengaruhi pola pikir dan tingkah laku anak. Hal ini sudah diterapka pada keluarga Si N, dimana orang tua bahkan keluarag dan teman-temannyaapalgi pihak guru sealu memotivasi $\mathrm{Si} N$ untuk rajin belajar dan mengoptimalkan belajar di rumah. Sedangkan pada diri Si A, tidak adanya motivasi yang diberikan orang tua kepada Si A, karena orang tua Si A sudah berpisah dan memiliki keluarga masing-masing. Sehingga tidak bisa mengurus dan mengawasi pergaulan dan tingkah laku dari Si A. Ia hanya sering mendapatkan motivasi belajar dari nenek nya saja. Hal itu lantas tak membuat Si A tidak memperdulikan neneknya. Si A sangat ingin merasakan perhatian dan juga motivasi dari orang tuanya. Dimana dulu waktu orang tuanya masih hidup bersama, Si A anak yang rajin, baik dan patuh kepada orang tuanya. Tetapi setelah orang tuanya berpisah, ia merasa kurang diperhatikan lagi, Si A kurang kasih sayang dari orang tuanya, sehingga Si A hanya berbuat sesuatu yang membuatnya nyaman, tanpa memikirkan apakah hal yang dilakukan tersebut baik atau tidak. Sehingga dilihat dari kesehariannya, Si A malah jadi anak yang kurang baik, karena bergaul bersama anak yang kurang baik pula.

\section{SIMPULAN}

Berdasarkan penelitian tersebut, diperoleh kesimpulan bahwa kesiapan belajar $\mathrm{Si}$ $\mathrm{N}$ menghadapi ujian sudah optimal. Si N sudah mempersiapakan diri menghadapi ujian baik dari segi fisik dan mentalnya. Sementara kesiapan belajar Si A menghadapi ujian belum optimal dikarenakan karena jarangnya ia mengikuti pelajaran yang diberikan guru dan seringnya ia bolos. Penghambat peserta didik dalam menghadapi ujian, karena kurangnya motivasi dan dukungan yang diberikan orang tua dan pengaruh pergaulan lingkungan.

\section{DAFTAR PUSTAKA}

Bungin, Burhan. (2007). Penelitian Kualitatif. Jakarta; Kencana.

Daryanto. (2013). Inovasi Pembelajaran efektif. Bandung: Yrama Widya.

Emzir. (2014). Metodologi Penelitian Kualitatif Analisis Data; Jakarta: PT Raja Grafindo Persada.

Mudjiono dan Dimyati. (2002). Belajar dan Pembelajaran. Jakarta: Rineka Cipta.

Rahman Ulfiani. (2014). Memahami Psikologi dalam Pendidikan Teori dan Aplikasi. Makassar: Alauddin University Press.

Sanjaya, Wina. (2006). Strategi Pembelajaran Berorientasi Standar Proses Pendidikan, Cet I. Jakarta: Kencan.

Steren, C. D Robert. (1990). Kuantitatif Dasar-Dasar Penelitian: Usaha Nasional, 1993. Supranto J. Metode Riset Aplikasinya Dalam Pemasaran; Jakarta: Lembaga Penerbit FE-UI. 
Sukmadinata, Syaodih Nana. (2010). Metode Penelitian Pendidikan,Bandung: PT. Remaja Rosdakarya.

Warsita, Bambang. (2001). Teknologi Pembelajaran Landasan dan Aplikasinya. Jakarta: Erlangga.

Yaumi, Muhammad. (2012). Desain Pembelajaran Efektif. Makassar: Alauddin University Press. 